\title{
EFEKTIFITAS PENERAPAN ANCAMAN SANKSI PIDANA TAMBAHAN GUNA PENGEMBALIAN KERUGIAN KEUANGAN NEGARA DALAM TINDAK PIDANA KORUPSI (STUDI KASUS DI PENGADILAN NEGERI DENPASAR) Oleh : \\ Kadek Krisna Sintia Dewi ${ }^{1}$
}

\begin{abstract}
Research on the effectiveness and the application of criminal sanctions and punishment in addition to return financial losses caused by corruption ( case study at the Denpasar District Court ) aims to describe and analyze deeply, about the effectiveness of additional punishment, including the return of financial loss caused by corruption. In addition, this study also aims to determine and assess the constraints in the implementation of court decisions related to the return of financial loss. Based on this articles, the question that is whether the application of additional criminal sanction and punishment, including the return of state losses can be effective pursuant to the provisions of Article 18 of Law No. 31 Year of 1999 on Eradication of Corruption Jo . Law No. 20 year of 2001 on the Amendment of the Law No. 31 Year of 1999 on Eradication of Corruption. The method used in this research is the method of empirical juridical legal research of the descriptive research using primary and secondary data sources by document studying and interview techniques as well as articles related to the issues. Based on the research that has been done, it can be seen that the application of the additional sanction and punishment, including the return of state losses have applied but unfortunately have not been able to be effective in the aim of recovery effort of state losses due to corruption, and reduce the amount of corruption that occurred in the Denpasar District Court Jurisdiction. It is based on the data corruption cases in the year of 2012 increased from 20 cases to 25 cases in 2013. Returns of state losses in 2012 - 2013 amounted Rp.871.273.192 which is the corruption amount cases in the year of 2010 - 2011. While the corruption cases in the year of 2012 - 2013, until recent time there are no recorded return of state losses. The constraints in the implementation of the court decisions related to the return of state losses, is convicted assets and property that has been transfered, multiple population administration, and duration of the judicial process to verdict and binding execution to be carried out .
\end{abstract}

Keywords : effectiveness, additional sanction and punishment, the return loss, corruption

\footnotetext{
${ }^{1}$ Mahasiswa Magister Ilmu Hukum Universitas Udayana, Denpasar, Bali. Alamat JL. Ratna Gang Melati No.9 Denpasar, e-mail: kadek_crisnha@yahoo.com
} 


\section{PENDAHULUAN}

\section{Latar Belakang Masalah :}

Tindak pidana korupsi adalah suatu perbuatan tidak jujur dengan maksud untuk memperkaya diri sendiri dan atau orang lain dengan cara menyelewengkan ataupun menggelapkan keuangan negara sehingga dapat menimbulkan kerugian terhadap keuangan negara.

Maraknya kasus korupsi yang terjadi di Indonesia, tidak dapat dipungkiri akan berdampak pada berbagai aspek kehidupan masyarakat baik dari segi perekonomian, keamanan serta stabilitas negara.

Sebagai salah satu kejahatan yang diklasifikasikan sebagai white collar crime, tindak pidana korupsi tidak hanya diperangi di Indonesia namun telah menjadi atensi masyarakat dunia. Salah satu bukti bahwa perang melawan korupsi menjadi tujuan negara dunia tercantum dalam Kongres PBB ke-8 yang merumuskan banyaknya akibat yang timbulkan akibat korupsi.

Salah satu negara yang giat melakukan pemberantasan terhadap korupsi adalah Malaysia. Langkah Malaysia dalam upaya meminimalisasi korupsi adalah dengan menggabungkan 3 Undang-undang sekaligus yakni Prevention of Corruption Act 1961 (Act 57), Emergency (Essential Power) Ordinance No.22, 1970, Anti Corruption Agency Act 1982 (Act 271) mejadi Anti Corruption Act Tahun 1997 (ACA) yang masih berlaku hingga saat ini. Berdasarkan ACA tersebut, dibentuklah Badan Pencegah Rasuah guna mewujudkan Malaysia bersih dari korupsi.

Tindak pidana korupsi merupakan salah satu dari beberapa tindak pidana khusus yang diatur juga diluar KUHP. Tindak pidana korupsi memiliki spesifikasi khusus yang membedakannya dengan tindak pidana umum misalnya dalam hal penyimpangan hukum acara dan materi yang diatur guna menekan jumlah kebocoran dan penyimpangan keuangan negara. ${ }^{2}$

Dalam suatu tulisannya, Gede Pasek Suardika menyatakan bahwa korupsi dalam bahasa sederhananya adalah tindakan melawan hukum yang menyebabkan terjadinya kerugian negara yang disebabkan oleh orang atau kelompok sehingga mengakibatkan kesempatan rakyat untuk mendapatkan anggaran pembangunan menjadi hilang, minimal berkurang. ${ }^{3}$

Berbagai upaya telah dilakukan pemerintah Inodnesia untuk menanggulangi serta memberatas korupsi, salah satu nya dengan terus memperbaharui peraturan perundang-undangan terkait tindak pidana korupsi. Saat ini yang menjadi payung hukum dalam penegakan hukum tindak pidana korupsi di Indonesia adalah Undang-undang

\footnotetext{
${ }^{2}$ Lilik Mulyadi, 2007, Pembuktian Beban Pembuktan, PT.Alumi Bandung, hal.,4

${ }^{3}$ Gupt\&Rekan, 2012, Korup \&Orup, Sinarpada, Bandung, hal. 83
} 
Nomor 31 Tahun 1999 tentang

Pemberantasan Tindak Pidana Korupsi Jo.

Undang-undang Nomor 20 Tahun 2001

tentang Perubahan Atas UU Nomor 31 Tahun

1999 tentang Pemberamtasan Tindak Pidana

Korupsi.

Esensi terpenting dari pemberantasan tindak pidana korupsi adalah upaya untuk memperoleh kembali kerugian keuangan negara akibat korupsi. Kerugian keuangan negara akibat korupsi terus meningkat setiap tahunnya, hal ini dikemukakan oleh Mardiasmo selaku Kepala BPKP yang mencatat bahwa pada tahun 2012, kerugian keuangan negara akibat korupsi mencapai Rp.9,72 triliun. ${ }^{4}$

Besarnya jumlah kerugian keuangan negara yang diakibatkan oleh korupsi menunutut penanganan serius dari pemerintah dan penegak hukum. Ketua KPK Abraham Samad menyatakan bahwa selama tahun 2013 KPK telah menyelamatkan keuangan negara sebesar Rp 1,196 Trilyun yang berasal dari pengembalian PNBP dari penanganan tindak pidana korupsi dan gratifikasi. ${ }^{5}$

\footnotetext{
${ }^{4}$ Ridwan Anshori, 2013, Selama 2012, Korupsi rugikan keyangan Negara Rp.9,72 T, http://daerah.sindonews.com/read/2013/10/24/22/7 87974/selama2012,korupsirugikannegaraRp9,72 T (diakses tanggal 12 Mei 2014)

${ }^{5}$ Voice Of Amerika, 2014, ICW : Pemberantasan Korupsi Indonesia Dalam 3 Tahun Terakhir http://www.voaindonesia.com/content/icwpemberantasan-korupsi-di-indonesia-dalam-3tahun-terakhir-meningkat/1847983.html, (diakses tanggal 12 Mei 2014)
}

Sejalan dengan hal tersebut, dari laporan tahunan KPK pada tahun 2011 masih tercatat adanya denda, uang pengganti serta biaya perkara yang masih dapat ditagih pada tahun 2011 yang berasal dari perkara pada tahun 2006 hingga 2011, ${ }^{6}$ sehingga hal ini menunjukan bahwa upaya memaksimalisasi pengembalian kerugian keuangan negara akibat tindak pidana korupsi masih mengalami hambatan.

Sebagai lembaga penegak hukum yang memiliki kewenangan khusus dalam penanganan kasus korupsi, tidak dapat dipungkiri bahwa KPK juga mengalami banyak kendala. Sehingga, dapat disadari bahwa upaya pemberantasan korupsi dan pengembalian kerugian keuangan negara akibat korupsi di daerah juga menemui banyak hambatan. Salah satunya adalah penanganan kasus korupsi di Pengadilan Negeri Denpasar. Sebagai upaya guna meningkatkan kinerja lembaga penegak hukum mengingat semakin maraknya kasus korupsi yang terjadi di Bali, maka pada tahun 2012 dibangunlah Pengadilan Tindak Pidana Korupsi di Bali dibawah naungan Pengadilan Negeri Denpasar. Pengadilan Tipikor Bali ini memeriksa dan memutus semua kasus korupsi yang berasal dari 8 Kabupaten yang ada di Bali. Sehingga dengan kata lain, seluruh kasus korupsi sejak tahun 2012 yang

\footnotetext{
${ }^{6}$ Rilis Laporan Tahunan KPK Tahun 2011 hal.55
} 
terjadi di Bali, terpusat di Pengadilan Tipikor

Denpasar.

Pelaksanaan pengembalian kerugian keuangan negara akibat tindak pidana korupsi juga tidak serta merta dapat begitu saja dilakukan. Selain menunggu pembayaran uang pengganti dari para terpidana kasus korupsi yang memerlukan waktu yang lama, pengembalian uang pengganti ke kas negara tidak dapat langsung dilakukan. Hal ini diakibatkan harus ada prosedur birokrasi yang dilewati, sehingga membutuhkan waktu untuk mengembalikan kerugian negara ke kas negara agar dapat segera digunakan untuk kesejahteraan rakyat.

Walaupun telah diatur secara tegas dalam ketentuan Undang-undang pemberantasan korupsi, namun upaya memberantas korupsi serta pengembalian kerugian keuangan negara akibat korupsi masih terkendala banyak faktor. Hal serupa juga terjadi ketika pelaksanaan putusan pengadilan menyangkut pidana tambahan berupa pengembalian kerugian keuangan negara masih terganjal banyak kendala.

\section{Permasalahan:}

Adapun permasalahan yang dapat ditarik dari uraian tersebut diatas adalah sebagai berikut :

1. Bagaimanakah penerapan ancaman sanksi pidana tambahan guna pengembalian kerugian keuangan negara dalam tindak pidana korupsi?
2. Apakah yang menjadi kendala dalam pelaksanaan Putusan Pengadilan terkait sanksi pidana tambahan guna pengembalian kerugian keuangan negara dengan uang pengganti dalam tindak pidana korupsi?

\section{Tujuan Penelitian}

\section{a. Tujuan Umum}

Untuk mengkaji dan menganalisis penerapan ancaman sanksi pidana tamabahan guna pengembalian kerugian keuangan negara dalam Undang-undang Korupsi.

\section{b. Tujuan Khusus}

1) Untuk mengkaji dan menganalisis penerapan ancaman sanksi pidana tambahan guna pengembalian kerugian keuangan negara dalam tindak pidana korupsi

2) Untuk mengkaji dan menganalisis apa saja yang menjadi kendala .

\section{METODE PENELITIAN :}

Penelitian ini adalah jenis penelitian hukum yuridis empiris. Dalam hal ini adalah penelitian mengenai penerapan ancaman sanksi pidana tambahan guna pengembalian kerugian keuangan negara dalam tindak pidana korupsi di Pengadilan Negeri Denpasar. Sifat penelitian ini adalah deskriptif yang mempergunakan data primer dan sekunder. Data primer diperoleh langsung 
dari informan. ${ }^{7}$ Para informan tersebut, antara lain: Hakim Pengadilan Negeri Denpasar, dan Jaksa di Kejaksaan Negeri Denpasar. Data sekunder didapat dari buku, karya ilmiah, dan peraturan perundang-undangan yang berkaitan dengan penelitian. ${ }^{8}$

\section{PEMBAHASAN}

1. Penerapan ancaman sanksi pidana tambahan guna pengembalian kerugian keuangan negara dalam tindak pidan korupsi

Tindak pidana korupsi adalah suatu perbuatan melawan hukum yang dilakukan oleh seorang pejabat negara (pegawai negeri) maupun korporasi dengan niat jahat atau curang guna memperkaya diri sendiri serta memperoleh kepentingan pribadi maupun kelompok yang menimbulkan kerugian negara serta perekonomian negara. Korupsi merupakan ancaman bagi terhadap cita-cita menuju masyarakat adil dan makmur. ${ }^{9}$

Keuangan negara tidak hanya sebatas uang semata, namun termasuk juga semua hak dan kewajiban negara yang dapat dinilai dengan uang, serta semua yang dapat dijadikan milik negara baik yang berada dalam penguasaan pemerintah maupun

7 Amirruddin dan H. Zainal Asikin, 2008, Pengantar Metode Penelitian Hukum, Ed. 1-4, PT RajaGrafindo Persada, Jakarta, hal. 30.

${ }^{8}$ Zainuddin Ali, 2011, Metode Penelitian Hukum, Cetakan Ketiga, Sinar Grafika, Jakarta, hal. 106.

${ }^{9}$ Evi Hartanti, 2007, Tindak Pidana Korupsi, Edisi Kedia, Sinar Grafika, Jakarta,. hal.1 penguasaan pihak lain diluar pemerintah. Yang dimaksud dengan kerugian negara adalah berkurangnya kekayaan Negara karena tindakan penyalahgunaan wewenang seseorang karena kedudukan dan jabatannya.

Istilah pidana sering diartikan sebagai hukuman. Penjatuhan sanksi berupa pidana biasanya dilakukan oleh penguasa kepada seseorang yang dianggap telah melanggar suatu aturan hukum. ${ }^{10}$

Sebagai upaya guna menjaga ketentraman serta sarana kontrol masyarakat, sanksi pidana merupakan hukuman yang paling sering digunakan untuk mewujudkan hal tersebut. Jenis ancaman sanksi pidana telah diatur dalam ketentuan Pasal 10 KUHP.

Ancaman sanksi pidana terkait tindak pidana korupsi diatur tersendiri dalam Undang-undang Pemberantasan Korupsi. Selain pidana pokok, Undang-undang Pemberantasan Korupsi juga mencantumkan pidana tambahan berupa pengembalian kerugian keuangan negara yang tercantum dalam dalam ketentuan Pasal 18 Undangundang Nomor 31 Tahun 1999 tentang Pemberantasan Tindak Pidana Korupsi Jo.Undang-undang Nomor 20 Tahun 2001 tentang Perubahan Atas Undang-undang Nomor 31 Tahun 1999.

10 Jan Remmelink, 2003, Hukum Pidana, Komentar Atas Pasal-Pasal Terpenting dari Kitab Undang-Undang Hukum Pidana Belanda dan Padanannya dalam Kitab Undang-Undang Hukum Pidana Indonesia, PT. Gramedia Pustaka Utama, Jakarta, h.7 
Penjatuhan sanksi pidana kepada koruptor adalah untuk menimbulkan efek jera, mengambalikan kerugian keuangan negara, serta sebagai upaya pencegahan agar masyarakat takut untuk melakukan tindak pidana korupsi. $^{11}$

Dalam penelitian ini lebih khusus membahas mengenai ancaman sanksi pidana tambahan guna pengembalian kerugian keuangan negara akibat tindak pidana korupsi dalam bentuk pembayaran uang pengganti yang ditetapkan dalam Putusan Pengadilan.

Pada hakikatnya teori pengembalian kerugian keuangan negara merupakan teori yang menjelaskan bahwa sistem hukum pengembalian kerugian keuangan negara berlandaskan pada prinsip keadilan sosial, dimana prinsip dasarnya adalah "berikan kepada negara apa yang menjadi hak negara". 12

Keuangan negara menurut Geodhart pada intinya merupakan keseluruhan undangundang yang ditetapkan guna memperoleh kekuasaan pemerintah untuk melaksanakan pengeluaran dalam periode tertentu dan menunjukkan alat pembiayaan yang

\footnotetext{
${ }^{11}$ Aziz Syamsudin, 2011, Tindak Pidana Khusus, Sinar Grafika, Jakarta, hal 155

${ }^{12}$ M.Akil Mochtar, 2006, Memberantas Korupsi Efektifitas Sistem Pembalikan Beban Pembuktian Dalam Gratifikasi, Q-Communication, Jakarta, hal.38
}

diperlukan untuk menutup pengeluaran tersebut. $^{13}$

Terkait penerapan ancaman sanksi pidana tambahan guna pengembalian kerugian keuangan negara dalam tindak pidana korupsi di Pengadilan Negeri Denpasar pada tahun 2012-2013 adalah sebagai berikut :

\footnotetext{
${ }^{13}$ Arsyad, H. Jawade Hafidz, 2013, Korupsi Dalam Perspektif HAN (Hukum Administrasi Negara), Sinar Grafika, Jakarta, hal.165.
} 
PERKARA KORUPSI DI PENGADILAN NEGERI DENPASAR TAHUN 2012

\begin{tabular}{|l|l|l|l|l|}
\hline NO. & \multicolumn{1}{|c|}{ NO.PERKARA } & \multicolumn{1}{|c|}{ TERDAKWA } & \multicolumn{1}{|c|}{$\begin{array}{c}\text { Puntutan pidana } \\
\text { tambahan }\end{array}$} & \multicolumn{1}{|c|}{$\begin{array}{c}\text { Pidana Tambahan } \\
\text { Pengembalian } \\
\text { Kerugian Keuangan } \\
\text { Negara }\end{array}$} \\
\hline 1. & 1/Pid.Sus/TPK/2012/PN.Dps & Desak Putu Ari Padmini & $\mathbf{2 9 0 . 9 9 8 . 7 5 0}$ & 290.998.750 (inkracht) \\
\hline 2. & 2/Pid.Sus/TPK/2012/PN.Dps & I Made Widarma & - & Tidak ada \\
\hline 3. & 3/Pid.Sus/TPK/2012/PN.Dps & I Wayan Gunawan & - & Tidak ada \\
\hline 4. & 4/Pid.Sus/TPK/2012/PN.Dps & H.Asmuni Turyadi & - & Tidak ada \\
\hline 5. & 5/Pid.Sus/TPK/2012/PN.Dps & I Wayan Armawa & - & Tidak ada \\
\hline 6. & 6/Pid.Sus/TPK/2012/PN.Dps & Bambang Subagyo & - & Tidak ada \\
\hline 7. & 7/Pid.Sus/TPK/2012/PN.Dps & Dra. Tety Gemeniawati & - & Tidak ada \\
\hline 8. & 8/Pid.Sus/TPK/2012/PN.Dps & I Made Budiarta & - & Tidak ada \\
\hline 9. & 9/Pid.Sus/TPK/2012/PN.Dps & Ni Nyoman Rusmini & - & Tidak ada \\
\hline 10. & 10/Pid.Sus/TPK/2012/PN.Dps & I Gede Putu Sunarta & - & Tidak ada \\
\hline 11. & 11/Pid.Sus/TPK/2012/PN.Dps & Priat Eko Purwo & - & Tidak ada \\
\hline 12. & 12/Pid.Sus/TPK/2012/PN.Dps & Rudi Hartono & - & Bebas \\
\hline 13. & 13/Pid.Sus/TPK/2012/PN.Dps & I Nengah Arnawa, dk & $\mathbf{1 . 3 9 5 . 0 0 0 . 0 0 0}$ & $\mathbf{1 . 3 9 5 . 0 0 0 . 0 0 0 ~ ( P K ) ~}$ \\
\hline 14. & 14/Pid.Sus/TPK/2012/PN.Dps & I Nyoman Oka Dhiputra & - & Tidak ada \\
\hline 15. & 15/Pid.Sus/TPK/2012/PN.Dps & I Nengah Sugita & - & Bebas \\
\hline 16. & 16/Pid.Sus/TPK/2012/PN.Dps & Nyoman Pastika & $\mathbf{2 9 . 9 2 1 . 7 5 3}$ & $\mathbf{2 9 . 9 2 1 . 7 5 3 ~ ( B a n d i n g ) ~}$ \\
\hline 17. & 17/Pid.Sus/TPK/2012/PN.Dps & I Wayan Kari Bagas Pramanta & $\mathbf{6 2 5 . 6 7 0 . 0 0 0}$ & 625.670.000 (Banding) \\
\hline 18. & 18/Pid.Sus/TPK/2012/PN.Dps & Ida Ayu Sri Astuti & - & Tidak ada \\
\hline 19. & 19/Pid.Sus/TPK/2012/PN.Dps & Putu Bagiada & $\mathbf{5 7 4 . 7 0 9 . 3 2 6}$ & 574.709.326 (Kasasi) \\
\hline 20. & 20/Pid.Sus/TPK/2012/PN.Dps & I Wayan Gobang Edy Sucipto & - & Tidak Ada \\
\hline
\end{tabular}

Sumber : Buku Register Perkara Tindak Pidana Korupsi Tahun 2012 PN.Dps

\section{PERKARA KORUPSI DI PENGADILAN NEGERI DENPASAR TAHUN 2013}

\begin{tabular}{|c|c|c|c|c|}
\hline NO. & NO.PERKARA & TERDAKWA & Tuntutan Pidana tambahan & $\begin{array}{c}\text { Pidana Pengembalian } \\
\text { Kerugian Negara }\end{array}$ \\
\hline 1. & 1/Pid.Sus/TPK/2013/PN.Dps & I Wayan Sukaja & 455.000.000 & 431.000.000 (Kasasi) \\
\hline 2. & 2/Pid.Sus/TPK/2013/PN.Dps & I Made Wardana & - & Tidak Ada \\
\hline 3. & 3/Pid.Sus/TPK//2013/PN.Dps & I Ketut Rana & - & Tidak Ada \\
\hline 4. & 4/Pid.Sus/TPK/2013/PN.Dps & Nengah Londen & - & Tidak Ada \\
\hline 5. & 5/Pid.Sus/TPK/2013/PN.Dps & I Made Yasa & - & Bebas \\
\hline 6. & 6/Pid.Sus/TPK/2013/PN.Dps & Nengah Artabawa & - & Tidak Ada \\
\hline 7. & 7/Pid.Sus/TPK/2013/PN.Dps & I Dewa Gede Ramayana & 63.820 .000 & 62.745.000 (inkracht) \\
\hline 8. & 8/Pid.Sus/TPK/2013/PN.Dps & Putu Santika & 85.567 .500 & Bebas \\
\hline 9. & 9/Pid.Sus/TPK/2013/PN.Dps & Gede Budiasa & 1.863.126.650 & 1.863.126.650 (inkracht) \\
\hline 10. & 10/Pid.Sus/TPK/2013/PN.Dps & I Made Kangen & - & Tidak ada \\
\hline 11. & 11/Pid.Sus/TPK/2013/PN.Dps & I Wayan Budiarsa & 91.510 .000 & 102.890.000 (inkracht) \\
\hline 12. & 12/Pid.Sus/TPK/2013/PN.Dps & I Wayan Ranuh & 135.000 .000 & 135.000.000 (Kasasi) \\
\hline 13. & 13/Pid.Sus/TPK/2013/PN.Dps & I Ketut Rustiani & 25.200 .000 & 25.200.000 (Inkracht) \\
\hline 14. & 14/Pid.Sus/TPK/2013/PN.Dps & I Dewa Putu Djati & - & Bebas \\
\hline 15. & 15/Pid.Sus/TPK/2013/PN.Dps & I Dewa Nyoman Putra, dk & - & Bebas \\
\hline 16. & 16/Pid.Sus/TPK/2013/PN.Dps & I Nyoman Mudjarta & - & Bebas \\
\hline 17. & 17/Pid.Sus/TPK/2013/PN.Dps & I Ketut Suardi & 100.000 .000 & Tidak Ada \\
\hline 18. & 18/Pid.Sus/TPK/2013/PN.Dps & I Ketut Tamtam & 2.693.489,92 & Tidak Ada \\
\hline 19. & 19/Pid.Sus/TPK/2013/PN.Dps & I Nengah Wijaya & 200.000 .000 & 200.000.000 (inkracht) \\
\hline 20. & 20/Pid.Sus/TPK/2013/PN.Dps & Ida Bagus Dedi Mahendra & 65.200 .500 & 65.200.500 (inkracht) \\
\hline 21. & 21/Pid.Sus/TPK/2013/PN.Dps & Ida Bagus Putu Sutika & 10.000 .000 & Tidak ada \\
\hline 22. & 22/Pid.Sus/TPK/2013/PN.Dps & I Wayan Budra & - & Tidak ada \\
\hline 23. & 23/Pid.Sus/TPK/2013/PN.Dps & Inderapura Barnoza & - & Tidak ada \\
\hline 24. & 24/Pid.Sus/TPK/2013/PN.Dps & Mikhael Maksi & - & Tidak ada \\
\hline 25. & 25/Pid.Sus/TPK/2013/PN.Dps & Rudi Jhonson Sitorus & - & Tidak ada \\
\hline
\end{tabular}


Berdasarkan data tersebut diatas dapat diketahui bahwa penerapan ancaman sanksi pidana tambahan guna penembalian kerugian keuangan negara di Pengadilan Negeri Denpasar telah diterapkan namun belum optimal. Hal ini karena masih adanya tuntutan Jaksa Penuntut Umum yang tidak mencantumkan pidana tambahan.

Berdasarkan data perkara korupsi 2012 di Pengadilan Negeri Denpasar, dari 20 kasus korupsi yang diperiksa di Pengadilan Tipikor Denpasar terdapat 5 kasus yang dalam amar putusannya berisi selain pidana penjara dan pidana denda juga berisi pidana tambahan berupa pengembalian kerugian. Sedangkan pada tahun 2013 dari 25 kasus yang terdaftar, terdapat 8 perkara yang amar nya mencantumkan pidana pengembalian kerugian keuangan negara dengan uang pengganti selain pidana penjara dan pidana denda. Dengan kata lain, penerapan ancaman sanksi pidana tambahan guna pengembalian kerugian keuangan negara di Pengadilan Negeri Denpasar tidak dapat dijadikan sebagai sarana guna mencegah terjadinya tindak pidana korupsi, karena walaupun ancaman pidana tambahan berupa pengembalian kerugian keuangan negara telah diterapkan tidak membuat masyarakat takut untuk melakukan korupsi sehingga tindak pidana korupsi yang terjadi di wilayah hukum Pengadilan Negeri Denpasar justru mengalami peningkatan.
Jika dilihat dari amar putusan menyangkut pengembalian kerugian keuangan negara akibat tindak pidana korupsi di Pengadilan Tindak Pidana Korupsi Denpasar dari tahun 2012-2013 adalah sebesar Rp.5.801.461.979,-.. Oleh karena masih ada perkara yang dalam proses upaya hukum, pengembalian kerugian keuangan negara perkara korupsi yang telah mempunyai kekuatan hukum tetap (inkracht) dan sepatutnya telah dapat diekseusi adalah sebesar Rp. 2.610.160.900,- Sedangkan Total uang pengganti yang disetorkan oleh Kejaksaan Negeri Denpasar ke Kas Negara pada tahun 2012-2013 adalah sebesar Rp. 871.273.192,-. Kelima terpidana yang membayar uang pengganti tersebut adalah terpidana yang perkaranya dimulai sejak tahun 2009 hingga 2011. Sedangkan untuk perkara dari tahun 2012-2013, belum ada satupun yang membayar ataupun dapat dilakukan eksekusi uang pengganti sebagai pidana tambahan pengembalian kerugian keuangan negara. Hal ini membuktikan bahwa diperlukan waktu yang sangat panjang guna memperoleh pengembalian kerugian keuangan negara dengan uang pengganti dari para terpidana.

2. Kendala dalam pelaksanaan Putusan Pengadilan terkait sanksi pidana tambahan guna pengembalian kerugian keuangan negara dengan uang pengganti dalam tindak pidana korupsi 
Dalam hal pelaksanaan Putusan Pengadilan (eksekusi) hingga saat ini masih banyak hambatan yang harus dihadapi oleh jaksa selaku eksekutor. Begitu pula dalam proses pelaksanaan putusan pengadilan menyangkut pengembalian kerugian keuangan negara dengan uang pengganti melalui proses sita dan pelelangan harta benda milik terpidana.

Berdasarkan hasil wawancara dengan Bapak I Gede Agus Suraharta, Jaksa di Kejaksaan Negeri Denpasar menyebutkan bahwa kendala utama yang dialami Jaksa saat melakukan eksekusi terhadap harta benda seorang terpidana dalam kasus korupsi yang dipidana dengan pidana pengembalian kerugian keuangan negara dengan uang pengganti adalah terpidana kerapkali menyembunyikan harta bendanya dengan sebaik-baiknya. Bahkan terkadang ada Terpidana yang mengaku tidak memiliki sama sekali harta yang dapat disita dan dilelang untuk membayar uang pengganti. Saat ini lah Jaksa berperan guna menelusuri terlebih dahulu harta benda yang dimiliki oleh seorang Terdakwa.

Upaya hukum yang panjang juga merupakan hambatan dihadapi dalam proses pengembalian kerugian keuangan negara akibat tindak pidana korupsi, padahal esensi terpenting dalam pemberantasan tindak pidana korupsi adalah pengembalian sebesar- besarnya kerugian keuangan negara akibat korupsi.

Hambatan pelaksanaan pengembalian kerugian keuangan negara akibat tindak pidana korupsi jika dikaitkan dengan teori sistem hukum (Legal System Theory) yang dikemukakan oleh Lawrence M.Friedman, yang pada intinya adalah menyatakan bahwa suatu sistem hukum terdiri dari 3 (tiga) komponen yaitu :

a) Substansi hukum (Legal Substance), dalam hal ini yang dimaksud sebagai substansi hukum adalah aturan atau norma hukum terkait tindak pidana korupsi yakni Undang-undang Nomor 31 Tahun 1999 tentang Pemberantasan Tindak Pidana Korupsi Jo. Undangundang Nomor 20 Tahun 2001 tentang Perubahan Atas Undang-undang Nomor 31 Tahun 1999 tentang Pemberantasan Tindak Pidana Korupsi, serta peraturan perundang-undangan lain terkait tindak pidana korupsi. Namun, hingga saat ini belum ada peraturan yang jelas terkait tata cara pelaksanaan pengembalian kerugian keuangan negara dengan uang pengganti secara lebih terperinci dan tersendiri. Mengingat urgensi dari pengembalian kerugian keuangan negara akibat tindak pidana korupsi.

b) Struktur Hukum (Legal Structure), adalah adalah kerangka permanen, atau unsur tubuh lembaga dalam sistem hukum. 
Dalam hal ini yang dimaksud dengan struktur hukum adalah institusi penegak hukum sebagai salah satu unsur nyata dalam suatu sistem hukum, termasuk juga lembaga yang turut melaksanakan aturanaturan hukum. Dalam hal pengembalian kerugian keuangan negara harus ada koordinasi diantara penegak hukum, khususnya hakim dalam menjatuhkan putusan, dan jaksa yang nantinya melaksanakan putusan terutama terkait sita dan lelang terhadap harta benda terpidana kasus korupsi yang tidak membayar uang pengganti sebagai pidana pengembalian kerugian keuangan negara.

c) Budaya Hukum (Legal Culture), merupakan bagian dari budaya pada umumnya, yang dapat berupa adat istiadat, pandangan, cara berfikir dan tingkah laku yang dapat membentuk suatu kekuatan sosial yang bergerak mendekati hukum dengan cara-cara tertentu). Dalam hal ini yang dimaksud dengan budaya hukum adalah perilakuperilaku masyarakat dalam memandang hukum untuk dipatuhi serta ditaati. Budaya hukum masyarakat saat ini telah mengalami pergeseran kearah yang lebih acuh terhadap suatu aturan hukum. Terbukti dengan banyak nya kasus korupsi yang terjadi dengan melibatkan seluruh lapisan masyarakat, bukan saja dari kalangan pejabat namun kini telah menjalar kelapisan masyarakat biasa.

Hal serupa juga di sebutkan oleh Bapak Romulus Halolongan, Kepala Seksi Tindak Pidana Khusus Kejaksaan Negeri Denpasar, bahwa apabila dikaitkan dengan pendapat Soerjono Soekanto tentang 5 faktor yang mempengaruhi efektif tidaknya suatu sistem hukum yaitu :

a. Faktor hukumnya sendiri. Aturan yang mengatur tentang uang pengganti guna pengembalian kerugian keuangan negara belum jelas. Undang-undang yang berlaku saat ini tidak memparkan secara terperinci konsekuesi dilapangan saat proses eksekusi. Karena masih banyak perbedaan antara aturan dan praktek dilapangan.

b. Faktor penegak hukum, yaitu pihak-pihak yang membentuk maupun menerapkan hukum. Dalam hal ini adalah mengoptimalkan tugas Jaksa dalam perumusan dakwaan dan tuntutan yang nantinya mempengaruhi pertimbangan hakim dalam menjatuhkan putusan

c. Faktor sarana atau fasilitas yang mendukung penegakan hukum. Selain pengadilan tipikor, tempat penyimpanan barang hasil sita dan lelang juga masih kurang.

d. Faktor masyarakat, yaitu lingkungan dimana hukum itu berlaku atau diterapkan. Kesulitan utama dalam 
proses eksekusi harta benda terpidana karena harta benda telah diamankan. Informasi masyarakat sangat mambantu. Namun saat ini masyarakat kian enggan untuk memberikan informasi karena takut terbawa-bawa dalam kasus yang menjerat terpidana.

e. Faktor kebudayaan, yakni hasil karya, cipta dan rasa yang didasarkan pada karsa manusia didalam pergaulan hidup. Budaya kekeluargaan yang sangat kental, juga dapat menghambat proses eksekusi harta benda seorang terpidana karena seringkali hasil korupsi telah dititipkan maupun dihibahkan kepada keluarga maupun kerabatnya sehingga sulit untuk dilacak keberadaannya.

Keberhasilan pemberantasan tindak pidana korupsi tidak hanya terletak pada penegak hukum, namun perlu juga didukung oleh pemegang kekuasaan dan politik. Sangat disayangkan hingga saat ini perkembangan politik Indonesia justru menunjukkan banyaknya pemegang kekuasaan yang melakukan korupsi.

Terlepas dari lemahnya dukungan politis bagi penegak hukum dalam penanganan tindak pidana korupsi, kegagalan pemberantasan tindak pidana korupsi juga disebabkan oleh proses penegakan hukum itu sendiri, baik pada tahap penyelidikan, penyidikan, penuntutan, hingga persidangan. Bahkan menurut Karni Ilyas, dinilai sangat mengkhawatirkan karena penegak hukum telah terperangkap dalam korupsi itu sendiri. ${ }^{14}$

Banyaknya kendala yang dihadapi jaksa selaku eksekutor dalam melakukan eksekusi penyitaan serta lelang terhadap harta benda milik terpidana kasus korupsi guna pengembalian kerugian keuangan negara dengan uang pengganti, dapat disimpulkan sebagai berikut :

a. Waktu yang lama hingga suatu putusan memiliki kekuatan hukum tetap setelah melalui upaya hukum hingga Peninjauan Kembali agar dapat dilakukan eksekusi oleh Jaksa.

b. Domisili seorang terpidana juga menjadi hambatan sebab tidak dapat dipungkiri bahwa saat ini banyak orang yang memiliki kartu tandan penduduk (KTP) ganda guna menyembunyikan harta kekayaannya hasil korupsi.

c. Undang-Undang Pemberantasan Tindak Pidana Korupsi belum mengatur secara jelas apabila terpidana hanya mampu membayar sebagian pembayaran uang pengganti.

d. Kebanyakan terpidana kasus korupsi lebih memilih menjalani hukuman subsider pidana penjara/hukum badan daripada membayar uang pengganti.

\footnotetext{
${ }^{14}$ Karni Ilyas, 2000, Catatan Hukum II, Pustaka Sinar Harapan, Jakarta, h.10
} 
e. Apabila terpidana meninggal dunia, maka segala tuntutan dianggap gugur demi hukum termasuk dengan uang penggantinya. Apabila jaksa selaku pengacara negara mengajukan gugatan perdata kepada ahli waris terpidana, memerlukan waktu yang lebih panjang.

\section{Penutup}

\section{Kesimpulan}

Adapun simpulan yang dapat ditarik dari pembahasan diatas adalah :

1. Penerapan ancaman sanksi pidana tambahan guna pengembalian kerugian keuangan negara dalam tindak pidana korupsi di Pengadilan Negeri Denpasar sudah diterapkan namun belum optimal. Hal ini dikarenakan masih adanya tuntutan Jaksa yang tidak mencantumkan pidana tambahan sehingga mempengaruhi pertimbangan Hakim dalam menjatuhkan Putusan. Akibatnya, upaya pengembalian kerugian keuangan negara karena tindak pidana korupsi menjadi tidak maksimal.

2. Kendala yang dihadapi Jaksa selaku eksekutor dalam pelaksanaan Putusan Pengadilan terkait sanksi pidana tambahan guna pengembalian kerugian keuangan negara dengan uang pengganti dalam tindak pidana korupsi, diantaranya:

a. Waktu yang lama hingga suatu putusan memiliki kekuatan hukum tetap. b. Mudahnya memperoleh KTP ganda.

c. Undang-undang korupsi belum mengatur secara jelas apabila terpidana hanya mampu membayar sebagian pembayaran uang pengganti.

d. Banyaknya terpidana kasus korupsi lebih memilih menjalani hukuman subsider pidana penjara/hukum badan daripada membayar uang pengganti.

e. Apabila terpidana meninggal dunia, maka segala tuntutan dianggap gugur demi hukum termasuk dengan uang penggantinya. Apabila jaksa selaku pengacara negara mengajukan gugatan perdata kepada ahli waris terpidana, memerlukan waktu yang lebih panjang.

\section{Saran :}

1. Agar pengembalian kerugian keuangan negara akibat tindak pidana korupsi dapat dilakukan dengan maksimal, maka perlu dibentuk Peraturan Pemerintah terkait tata cara penghitungan serta tata cara pelaksanaan pembayaran uang pengganti guna pengembalian kerugian keuangan negara akibat tindak pidana korupsi.

2. Agar semua lembaga penegak hukum serta instansi terkait lebih giat 
melakukan penyuluhan anti korupsi kepada masyarakat guna meningkatkan kesadaran hukum masyarakat terkait pentingnya pengembalian kerugian keuangan negara akibat tindak pidana korupsi.

\section{DAFTAR PUSTAKA}

\section{Buku :}

Ali, Zainuddin, 2011, Metode Penelitian Hukum, Cetakan Ketiga, Sinar Grafika, Jakarta

Amirruddin dan H. Zainal Asikin, 2008, Pengantar Metode Penelitian Hukum, Ed. 1-4, PT RajaGrafindo Persada, Jakarta

Gupt \& Rekan, 2012, Korup\&Orup, Sinarpada, Bandung

Hafidz, Arsyad, H. Jawade 2013, Korupsi Dalam Perspektif HAN (Hukum Administrasi Negara), Sinar Grafika, Jakarta

Hartanti, Evi, 2007, Tindak Pidana Korupsi, Edisi Kedia, Sinar Grafika, Jakarta

Ilyas, Karni, 2000, Catatan Hukum II, Pustaka Sinar Harapan, Jakarta.

Mochtar, M.Akil, 2006, Memberantas Korupsi Efektifitas Sistem Pembalikan Beban Pembuktian Dalam Gratifikasi, Q-Communication, Jakarta.

Mulyadi, Lilik, 2007, Pembuktian Beban Pembuktan, PT.Alumi Bandung.
Remmelink, Jan, 2003, Hukum Pidana, Komentar Atas Pasal-Pasal Terpenting dari Kitab UndangUndang Hukum Pidana Belanda dan Padanannya dalam Kitab UndangUndang Hukum Pidana Indonesia, PT. Gramedia Pustaka Utama, Jakarta.

Syamsudin, Aziz, 2011, Tindak Pidana Khusus, Sinar Grafika, Jakarta

\section{Peraturan Perundang-undangan}

UU RI No.31 Tahun 1999 Jo.UU RI No. 20 Tahun 2001

\section{Internet :}

Ridwan Anshori, 2013, Selama 2012, Korupsi rugikan keyangan Negara Rp.9,72 T, http://daerah.sindonews.com/read/2013 /10/24/22/787974/selama2012,korupsir ugikannegaraRp9,72 $\mathrm{T}$ (diakses tanggal 12 Mei 2014)

Voice Of Amerika, 2014, ICW : Pemberantasan Korupsi Indonesia Dalam 3 Tahun Terakhir Meningkat, http://www.voaindonesia.com/content/i cw-pemberantasan-korupsi-diindonesia-dalam-3-tahun-terakhirmeningkat/1847983.html, (diakses tanggal 12 Mei 2014) 
